University of Nebraska - Lincoln

DigitalCommons@University of Nebraska - Lincoln

2010

\title{
Variation in Leaf Stomatal Traits of 28 Tree Species in Relation to Gas Exchange along an Edaphic Gradient in a Bornean Rain Forest
}

\author{
Sabrina E. Russo \\ University of Nebraska - Lincoln, srusso2@unl.edu \\ Whitney Logan Cannon \\ University of Nebraska - Lincoln \\ Christian Elowsky \\ University of Nebraska-Lincoln, celowsky@unl.edu \\ Sylvester Tan \\ Harvard University \\ Stuart J. Davies \\ Harvard University, daviess@si.edu
}

Follow this and additional works at: https://digitalcommons.unl.edu/bioscifacpub

Part of the Life Sciences Commons

Russo, Sabrina E.; Cannon, Whitney Logan; Elowsky, Christian; Tan, Sylvester; and Davies, Stuart J., "Variation in Leaf Stomatal Traits of 28 Tree Species in Relation to Gas Exchange along an Edaphic Gradient in a Bornean Rain Forest" (2010). Faculty Publications in the Biological Sciences. 160.

https://digitalcommons.unl.edu/bioscifacpub/160

This Article is brought to you for free and open access by the Papers in the Biological Sciences at DigitalCommons@University of Nebraska - Lincoln. It has been accepted for inclusion in Faculty Publications in the Biological Sciences by an authorized administrator of DigitalCommons@University of Nebraska - Lincoln. 


\title{
VARIATION IN LEAF STOMATAL TRAITS OF 28 TREE SPECIES IN RELATION TO GAS EXCHANGE ALONG AN EDAPHIC GRADIENT IN A BORNEAN RAIN FOREST ${ }^{1}$
}

\author{
Sabrina E. Russo $2,3,6$, Whitney Logan Cannon ${ }^{2}$, Christian Elowsky $^{4}$, \\ Sylvester TaN ${ }^{3,5}$, and Stuart J. Davies ${ }^{3}$ \\ ${ }^{2}$ School of Biological Sciences, University of Nebraska, Lincoln, Nebraska 68588 USA; ${ }^{3}$ Center for Tropical Forest \\ Science-Arnold Arboretum Asia Program, Harvard University, Cambridge, Massachusetts 02138 USA; \\ ${ }^{4}$ Center of Biotechnology, University of Nebraska, Lincoln, Nebraska 68588 USA; and ${ }^{5}$ Forest Research Centre, Sarawak \\ Forestry Corporation, Kuching, Sarawak, Malaysia
}

- Premise of the study: Quantifying variation in functional traits associated with shifts in the species composition of plant communities along resource gradients helps identify environmental attributes important for community assembly. Stomates regulate the balance between carbon assimilation and water status in plants. If environmental attributes affecting photosynthetic water-use efficiency govern species distribution along an edaphic gradient, then adaptive variation in stomatal traits of plant species specializing on different soils should reflect belowground resource availability.

- Methods: We tested this hypothesis by quantifying stomatal trait variation in understory saplings of 28 Bornean tree species in relation to gas exchange and water-use efficiency (WUE).

- Key results: Comparisons between congeneric specialists of the more fertile, moister clay and the less fertile, well-drained sandy loam revealed little evidence of similar shifts in stomatal traits across genera, nor was stomatal pore index correlated with $g_{\max }, A_{\max }$, or WUE $\left(A_{\max } / g_{\max }\right.$ or $\left.\Delta^{13} \mathrm{C}\right)$, suggesting that stomates may be overbuilt in these shaded juveniles. $A_{\max }$ was higher on sandy loam, likely due to higher understory irradiance there, but there were no other significant differences in gas exchange or WUE.

- Conclusions: Despite substantial diversity in stomatal anatomy, there were few strong relationships between stomatal, photosynthetic, and WUE traits in relation to soil resources. Routine differences in water availability therefore may not exert a dominant control on the distributions of these Bornean tree species. Furthermore, the clades represented by these 12 genera may possess alternative functional designs enabling photosynthetic WUE that is sufficient to these humid, understory environments, due to whole plant-functional integration of stomatal traits with other, unmeasured traits influencing gas exchange.

Key words: gas exchange; leaf functional traits; Malaysia; mixed dipterocarp forest; phenotypic plasticity; photosynthetic rate; phylogenetic comparisons; stable isotope ${ }^{13} \mathrm{C}$; stomatal conductance; water-use efficiency.

The ecological roles of plant species can be described by their functional traits, which are physiological, morphological, or anatomical characteristics facilitating the acquisition of light, water, carbon, and mineral nutrients, the essential resources for plant growth, survival, and reproduction. Functional traits often covary consistently along environmental gradients that shift in

\footnotetext{
1 Manuscript received 10 November 2009; revision accepted 29 April 2010. The authors thank the Sarawak Forest Research Corporation for their kind permission to conduct research in Lambir Hills National Park. The 52-ha Long-Term Ecological Research Project is a collaborative project of the Forest Department of Sarawak, Malaysia, Harvard University, USA (under NSF awards DEB-9107247 and DEB-9629601 to P.S. Ashton), and Osaka City University, Japan (under Monbusho grant 06041094 to T. Yamakura, 08NP0901 to S. Tamura, and 09NP0901 to S. Sasaki). Leaves were collected while S.E.R. was supported by the Center for Tropical Forest Science-Arnold Arboretum Asia program of Harvard University. W.L.C. was supported as an undergraduate student by the Environmental Studies program of the University of Nebraska, Lincoln. They are grateful to the Microscopy Core Facility of the University of Nebraska-Lincoln for use of the facility, to L. Sack for insightful discussions about stomates, and to T. Arkebauer, H. Griffiths, and H. Maherali for constructive comments on an earlier draft of this article.

6 Author for correspondence (e-mail: srusso2@ @unl.edu)
}

doi:10.3732/ajb.0900344 resource availability (Chapin, 1980; Grime, 2001; Reich et al., 2003). Such suites of covarying functional traits are considered evidence of coordinated ecological strategies that reflect correlated evolution and that underlie floristic variation at many scales (Westoby et al., 2002; Ackerly, 2003; Reich et al., 2003). Analyses of functional trait variation on resource gradients therefore provide a means to link patterns in species composition with the environmental attributes that are important for community assembly (Weiher and Keddy, 1999; Ackerly, 2003).

Natural selection should favor plants with suites of functional traits that maximize their net rate of carbon gain, contingent on survival (Givnish, 1988). Traits that maximize carbon gain, such as the ability of the leaf to support high maximum stomatal conductance $\left(g_{\max }\right)$ and fast rates of transpiration and photosynthesis $\left(A_{\max }\right)$, should therefore experience positive selection in environments favoring fast growth, such as more fertile, mesic habitats (Chapin, 1980). Conversely, the capacity to avoid desiccation and increase water-use efficiency should reflect selection to minimize water loss in environments with reduced water availability, while simultaneously optimizing carbon gain (Chapin et al., 1993; Kozlowski and Pallardy, 2002). Because of their dual role in mediating the balance between carbon assimilation and water status, adaptive variation in stomatal traits of plant species specializing on different habitats should mirror the availability of resources affecting these functions. Here, we 
test this idea using data on stomatal and gas-exchange traits of tree species specializing on contrasting soil types in ever-wet Bornean rain forest.

As the terminal element of the hydraulic system in higher plants, stomates mediate gas exchange between the leaf and atmosphere. Stomatal apertures change as a result of the direct and indirect responses of guard cells to environmental factors that affect carbon assimilation and evaporation of water, such as light, ambient humidity, temperature, $\mathrm{CO}_{2}$ concentration, and soil nutrient and water availability. The stomatal complex is therefore a pivotal structure that simultaneously acts to prevent desiccation of plant tissue and to vary the conductance to diffusion so as to optimize the balance between water vapor efflux and $\mathrm{CO}_{2}$ influx to the leaf in a varying environment (Cowan, 1978; Cowan and Farquhar, 1977). Indeed, stomatal and vascular traits controlling gas- and liquid-phase transport are often found to be functionally coordinated with the capacity of the photosynthetic system to fix $\mathrm{CO}_{2}$ (Meinzer, 2002; Sack et al., 2003; Maherali et al., 2008; Brodribb et al., 2009; Nobel, 2009).

Many environmental attributes affect carbon gain. Principal among these is light. In the understory of closed-canopy, tropical forest, which is the focus of our study, light is often extremely limiting (Chazdon and Pearcy, 1986). Identifying functional traits that determine carbon gain in low light is key to understanding the growth and survival of juvenile trees as they reach maturity. Understories of wet, tropical forest are also often humid and still, which reduces the leaf boundary layer conductance, which combined with low light, can limit the total leaf conductance to $\mathrm{CO}_{2}$ and, hence, the delivery of $\mathrm{CO}_{2}$ into the leaf (Hanba et al., 2003; Seibt et al., 2008). The availability of belowground resources also has important consequences for carbon gain. Soil moisture affects whole-plant hydraulic conductivity, which influences stomatal function by inducing stomatal movements that preserve a dynamic equilibrium between transpiration and hydraulic conductance while avoiding xylem cavitation (Meinzer et al., 1997; Brodribb et al., 2003). In addition, soil mineral nutrients are required to support photosynthetic catalytic capacity (e.g., chlorophyll and RuBisCO) (Chapin, 1980).

In northwest Borneo, the floristic composition of mixed dipterocarp rain forest varies along gradients of elevation and of soil texture, moisture, and fertility (Ashton, 1964; Baillie et al., 1987; Potts et al., 2002). Within a forest dynamics plot at Lambir Hills National Park (Lambir) in this region, most tree species have distributions restricted to particular soil types, causing high turnover in species composition along the gradient (Davies et al., 2005). Two soils, clay and sandy loam, are at the extremes of the moisture-fertility gradient: clay is more fertile and has greater water-holding capacity than sandy loam (Baillie et al., 2006) and is more productive in that it supports faster tree diameter growth rates (Russo et al., 2005).

We used this gradient to test hypotheses concerning the relationships between soil resource availability, anatomy of the stomatal complex, and gas-exchange and water-use efficiency parameters for 28 angiosperm tree species. If environmental attributes related to photosynthetic water-use efficiency govern species distribution on contrasting soil types, then variation in stomatal traits between clay vs. sandy loam specialists should reflect both the greater soil moisture and the larger gas exchange capacity required to support the faster growth rates observed on clay relative to sandy loam. We therefore expected tree species specializing on clay to have a higher density of larger stomates, resulting in larger stomatal pore area per unit lamina area on a leaf, relative to species specializing on sandy loam. We also expected larger stomatal pore area to be associated with faster maximum stomatal conductance and carbon assimilation rates and less efficient water use among species.

We evaluated these predictions using interspecific comparisons of stomatal density and guard cell length for 24 Bornean tree species representing congeneric species pairs (12 genera), in which one was a specialist of sandy loam and the other was a specialist of clay, and intraspecific comparisons within four generalists (similarly abundant on both clay and sandy loam). Comparisons between congeneric specialists allow a phylogenetically controlled test of whether there are consistent soilrelated shifts in stomatal, gas-exchange, and water-use efficiency traits, whereas comparisons between populations of generalist species growing on sandy loam and clay allow an assessment of phenotypic plasticity in stomatal traits. We predicted that the direction of within-species differences would parallel those predicted between specialists.

\section{MATERIALS AND METHODS}

Study site-This research was conducted in Lambir Hills National Park, Sarawak, Malaysia $\left(4^{\circ} 11^{\prime} \mathrm{N}, 114^{\circ} 01^{\prime} \mathrm{E}\right)$. The Park encompasses 6800 ha of lowland, mixed dipterocarp forest with the highest tree species richness ever recorded in the palaeotropics (Ashton and Hall, 1992; Lee et al., 2002). Rainfall is $3000 \mathrm{~mm} \cdot \mathrm{y}^{-1}$, with all months averaging $>100 \mathrm{~mm}$ (Watson, 1985). In 1991, a 52-ha plot (hereafter, Lambir) was established in the Park using methods from similar studies by the Center for Tropical Forest Science (Condit, 1998). All trees $\geq 1 \mathrm{~cm}$ in diameter, excluding palms ( $\sim 200$ woody species), were tagged, mapped, identified, and their diameters measured to the nearest $1 \mathrm{~mm}$, with recensuses every $\sim 5 \mathrm{yr}$.

Floristic composition, stand structure, soils, and geomorphology of Lambir are described in Lee et al. (2002), Baillie et al. (2006), and Tan et al. (2009). Soils range from coarse loams that are sandstone-derived, leached, nutrientdepleted and well drained, with substantial raw humus (named humult in previous studies), to clays that are shale-derived, less nutrient-depleted, and not as well drained, with little raw humus (previously named udult). Davies et al. (2005) identified four soil types in Lambir based on variation in nutrients (total $\mathrm{C}, \mathrm{N}$, and $\mathrm{P}$ and exchangeable $\mathrm{K}, \mathrm{Ca}$, and $\mathrm{Mg}$ ) and elevation at a $20 \times 20 \mathrm{~m}$ scale. Ranked in ascending order of fertility and moisture, they are: sandy loam, loam, fine loam, and clay. Means of total nitrogen, total phosphorus, $\mathrm{pH}$, exchangeable magnesium and calcium, and elevation for each of the four soil types are reported in Davies et al. (2005). Means for exchangeable and reserve nutrients, total exchangeable bases, cation exchange capacity, and base saturation the sandy loam and clay habitats are reported in Baillie et al. (2006).

The distributions of most tree species in Lambir are strongly biased with respect to these four soil types (Davies et al., 2005). Among the 764 species tested, $73 \%$ had distributions significantly aggregated on one or two soil types (specialists), and $13 \%$ had a neutral distribution with respect to soil fertility and topography (generalists). Here, we focused on 24 tree species specializing on the extremes of this edaphic gradient, sandy loam and clay, and four generalist species that are found on all soil types. From Davies et al. (2005), the means and standard errors (with their respective units) of selected mineral nutrient concentrations in surface soil of sandy loam and clay, respectively, are total $\mathrm{N}$ (\%): 0.093 (0.001) and 0.107 (0.003); total P (mg/kg): $43.7(0.7)$ and 133.6 (4.1); exchangeable $\mathrm{Mg}\left(\mathrm{cmol}_{\mathrm{c}} / \mathrm{kg}\right): 0.12(<0.01)$ and $0.70(0.04)$.

Soil volumetric water content, vapor pressure deficit, and understory light availability (see below) were measured to characterize the abiotic environment on sandy loam and clay soil. Three replicate measurements of soil volumetric water content were made $\sim 25 \mathrm{~cm}$ from each other at a location using a handheld time-domain reflectometer (HydroSense, Campbell Scientific, Logan, Utah) on a single, rain-free day approximately every 2-8 wk from June 2004 to May 2005 (13 measurement dates); 17 locations were sampled on sandy loam and clay soil (34 locations in total). Differences between soil types were tested with a repeated-measures analysis of variance with date of measurement treated as a random effect and soil type as a fixed effect.

Ambient vapor pressure deficit (VPD; $\mathrm{mmol} / \mathrm{mol}$ ) was calculated based on air temperature and relative humidity (Murray, 1967; Campbell, 1977) measured at $1 \mathrm{~m}$ above the soil at seven locations on each soil type from October to December 2007 (21 day-location combinations on each soil). Sensors 
(CS-215L, Campbell Scientific, Logan, Utah) were calibrated to each other in the laboratory and were rotated between locations every $3 \mathrm{~d}$, and maximum and minimum relative humidity and air temperature $\left({ }^{\circ} \mathrm{C}\right)$ were recorded every $15 \mathrm{~min}$.

Study species and individuals - The study species comprised 28 angiosperm tree species in 12 genera and 10 families (Table 1). All study species are shade-tolerant, $\mathrm{C}_{3}$ plants, but Macaranga lamellata and $M$. umbrosa are the most light-demanding. Study species were selected to represent phylogenetically controlled comparisons and thus were congeneric species pairs of sandy loam and clay specialists. For four of the 12 genera, a generalist species was also included. Interspecific comparisons of sandy loam and clay specialists within genera allow a test of the hypothesis that, across different genera, there have been consistent shifts in stomatal traits linked to shifts in soil-type specialization by these tree species. Generalists were sampled from individuals growing on both sandy loam and clay and allow assessment of the phenotypic plasiticity of stomatal traits in response to variation in edaphic resources.

All individual trees (1-3 cm in diameter at $1.3 \mathrm{~m}$ height) used in this study were selected randomly within the Lambir plot, conditional on appearing healthy with no major breaks in the stem or crown. To minimize variation in the light environment of study individuals, only trees growing in shade under fully closed canopy were selected. To account for the possibility that light availability affected estimates of gas exchange parameters and stomatal traits, hemispherical photographs were taken at $1-\mathrm{m}$ above the soil, centered under the crown of most study individuals ( $N=98$ trees) with a Nikon CoolPix 4500 using a FC-E8 fisheye lens converter. The study individual's crown was moved out of the image when the photograph was taken. Photographs were taken under uniform sky light conditions: early in the morning, on overcast days, and after sunset. Images were analyzed with Winscanopy software (Regent Instruments, Canada); canopy openness (\%) and total average daily photosynthetically active photon flux density under the canopy $\left(\mathrm{PPFD} ; \mathrm{mol} \cdot \mathrm{m}^{-2} \cdot \mathrm{day}^{-1}\right.$ ) were estimated for each tree. The mean canopy openness across all study individuals was $6.2 \%$ (standard deviation 1.3\%). In analyses in which the individual was the unit of replication, PPFD was included as a covariate (see below). Student's $t$ test was used to test for differences between the clay and sandy loam soils in canopy openness and PPFD.

Stomatal measurements-Leaves used for measurement of stomatal traits were collected from the Lambir plot in November 2005 from 3-8 trees per species $(N=165$ trees; Table 1$)$ growing under closed-canopy forest on their home soil type (specialists) or on both sandy loam and clay soils (generalists). Recent, mature, fully expanded leaves that were generally undamaged and largely free of epiphylls, lichens, or fungi were preferred and were immediately preserved in $100 \%$ ethanol. The terminal leaflet was used for measurements of compound leaves. Although impressions of the abaxial surface of the lamina of fresh leaves were initially made using fingernail varnish, we found the cell walls of guard cells to be poorly defined in the impressions, most likely because of the thick cuticles and layers of epicuticular wax typical of many tropical tree species. Instead, confocal microscopy (Olympus FluoView 500 on an Olympus BX60) of the preserved leaf tissue was used to make images of the abaxial and adaxial surfaces of laminas. Excitation was with a $405 \mathrm{~nm}$ diode laser, and emission spectra were detected in three channels: $430-460,505-525$, and 560$600 \mathrm{~nm}$. The autofluorescence of the walls of the leaf epidermal cells and of the extracellular components is highly visible on micrographs and clearly outlines the walls of guard cells.

For each specimen, three micrographs of the abaxial surface of the lamina were taken at $200 \times$ or $400 \times$ magnification (Appendix S1, see Supplemental Data at http://www.amjbot.org/cgi/content/full/ajb.0900344/DC1). Images were taken at haphazardly selected, nonoverlapping locations on $\sim 2-\mathrm{cm}^{2}$ sections of the leaf, taken from between the midrib of the lamina and its edge and in the middle of the length of the lamina. This area is likely to be the most photosynthetically active portion of the lamina. The density (number of stomates $\left.\mathrm{mm}^{-2}\right)$, guard cell length $(\mu \mathrm{m})$, and inner pore length $(\mu \mathrm{m})$ were measured on micrographs using Image-J software (Abramoff et al., 2004). For density, only the stomates for which the entire pore was visible in the field of view were counted. Guard cell length and inner pore length were measured on three haphazardly selected stomates per image. The stomatal pore index (SPI; a dimensionless index of stomatal pore area per lamina area measuring the stomatal conducting capacity of the leaf), was calculated as (stomatal density) $\times$ (guard cell length) ${ }^{2}$ on the abaxial surface of the lamina (Sack et al., 2003).

A more limited data set on stomatal traits was collected using scanning electron microscopy (online Appendix S1). Scanning electron micrographs (400× and $1200 \times$ magnification) were made at haphazardly selected, nonoverlapping locations on leaf punches $\sim 5 \mathrm{~mm}$ in diameter; the punch was made immediately adjacent to the section of the leaf used for confocal micrographs. The guard cell lengths for 2-19 stomates were measured using Image-J for 1-2 trees per species. Mean guard cell length measured using images from confocal and SEM micrographs were correlated among species $(r=0.81, P<0.001$; Appendix S2, see online Supplemental Data), and all analyses were consistent between the two types of measurements. Therefore, the results presented are based on the more extensive data from the confocal micrographs.

Gas-exchange and water-use efficiency parameters-Recent, mature, fully expanded leaves that were largely free of epiphylls, lichens, and damage were selected for estimation of gas exchange parameters and water-use efficiency. Maximum stomatal conductance $\left(g_{\max } ; \mathrm{mmol} \mathrm{H}_{2} \mathrm{O} \cdot \mathrm{m}^{-2} \cdot \mathrm{s}^{-1}\right)$ and carbon assimilation $\left(A_{\max } ; \mu \mathrm{mol} \mathrm{CO} \mathrm{CO}_{2}^{-2} \cdot \mathrm{s}^{-1}\right)$ rates were measured on naturally growing trees (1-3 cm in diameter) at Lambir on sunny days from June to October 2005 using a portable infra-red gas analyzer (LI-6400, LiCor Environmental Sciences, Lincoln, Nebraska, USA) on 2-4 individuals per species-soil-type combination ( $N=102$ trees). Leaves were first acclimated with light supplied by red-lightemitting diodes (LI-6400-02) having a photon flux density of $500 \mu \mathrm{mol} \cdot \mathrm{m}^{-2} \cdot \mathrm{s}^{-1}$. Once gas exchange rates had stabilized, light was increased progressively up to $1200 \mu \mathrm{mol} \cdot \mathrm{m}^{-2} \cdot \mathrm{s}^{-1}$, which was considered saturating. After gas exchange rates had again stabilized, several gas exchange measurements were recorded, and $A_{\max }$ and $g_{\max }$ were taken to be the averages of these measurements at steady state and saturating light. The $\mathrm{CO}_{2}$ concentration of the reference air entering the leaf chamber was adjusted with a $\mathrm{CO}_{2}$ mixer control unit to be $400 \mathrm{ppm}$ $\mathrm{CO}_{2}$. All gas exchange data were collected in the mornings between 0800 and 1200 hours. The chamber temperature was controlled by maintaining the Peltier block temperature at $30^{\circ} \mathrm{C}$. The relative humidity of the reference air was kept as close to ambient (usually $70-85 \%$ ) as possible. Leaf vapor pressure deficits within the leaf chamber were $<1.8 \mathrm{kPa}$ for all measurements. The air flow rate was $650 \mathrm{~mL} / \mathrm{min}$. Close examination of the data during and after measurements were complete showed no evidence of photoinhibition. Instantaneous water-use efficiency (WUE) was calculated as $A_{\max } / g_{\max }$.

The content of the stable isotope ${ }^{13} \mathrm{C}$ in leaves was used as an estimate of the WUE integrated over the period of leaf construction (integrated WUE; Farquhar et al., 1982). $\delta^{13} \mathrm{C}$ was quantified on $1-2$ leaves of $10-12$ trees per species-soil-type combination. Depending on leaf size, 1-3 leaves per individual were dried at $60^{\circ} \mathrm{C}$ for a minimum of $72 \mathrm{~h}$, finely ground together so as to pass through a 40-mesh screen, and analyzed for ${ }^{13} \mathrm{C}$ content on a Finnigan Delta $^{+}$mass spectrometer (Finnigan MAT, Bremen, Germany) coupled to a Carlo Erba elemental analyzer (NA1500 CHN combustion analyzer; Carlo Erba Strumazione, Milan, Italy) via a Finnigan Conflo II Interface at the University of Arkansas Stable Isotope Analysis Laboratory, USA.

To account for the possibility that differences in the ${ }^{13} \mathrm{C}$ content of the ambient source $\mathrm{CO}_{2}$ available for assimilation on each soil type might bias inferences concerning integrated WUE of species on sandy loam vs. clay, we quantified $\delta{ }^{13} \mathrm{C}$ in ambient air. Air samples at $1-\mathrm{m}$ height in the understory of 10 locations on each soil were collected in $100 \mathrm{~mL}$ glass flasks from 0800 to 1100 hours on $2 \mathrm{~d}$ using an air pump using methods similar to those in Lai et al. (2005). Air that had been dried with magnesium perchlorate was pumped through the flask for $\sim 2 \mathrm{~min}$, with the collection point $\sim 10 \mathrm{~m}$ from the observer to prevent exhaled $\mathrm{CO}_{2}$ from entering the flask. Flasks were shipped to the Stable Isotope Ratio Facility for Environmental Research at the University of Utah, where they were analyzed on a GC-IRMS system as in Schauer et al. (2003). Differences in $\delta^{13} \mathrm{C}$ of the source $\mathrm{CO}_{2}$ were tested using a linear, mixedeffect model with measurement date as a random effect and soil type as a fixed effect. $\delta^{13} \mathrm{C}$ was significantly higher on the sandy loam soil $(-9.39 \%$ ), relative to clay $(-10.39 \% ; t=2.59, \mathrm{df}=17, p=0.019)$. $\Delta 13 \mathrm{C}$ of leaf tissue was calculated as $\left(\delta_{\mathrm{a}}-\delta_{\mathrm{p}}\right) /\left(1+\delta_{\mathrm{p}}\right)$ where $\delta_{\mathrm{a}}$ is the $\delta^{13} \mathrm{C}$ of the source $\mathrm{CO}_{2}$ for the appropriate soil and $\delta_{\mathrm{p}}$ is the $\delta^{13} \mathrm{C}$ of the leaf tissue (Farquhar and Richards, 1984).

Statistical analysis - Differences in stomatal traits between clay and sandy loam specialists in each genus and between populations of generalists growing on clay or sandy loam in each species were analyzed using separate linear models for specialists and generalists. For specialists, differences between genera were modeled as fixed effects. The soil specialization (sandy loam or clay) of congeneric species was treated as a fixed effect nested within genus, because specialists were represented by different species in each case and were only sampled on their home soil type. For generalists, the model structure was the same, except the grouping factor was species. We chose a nested-effect design because we were interested in whether there was a significant effect of soil 
TABLE 1. Taxonomy, abbreviation codes, growth form, leaf arrangement, and soil specialization pattern of the 28 study species in Bornean rain forest. Sample sizes $(N)$ on sandy loam (SL) and clay (C) are the number of trees sampled for stomatal traits.

\begin{tabular}{|c|c|c|c|c|c|c|}
\hline Code & Species & Family & Growth form & Leaf arrangement & $\begin{array}{c}\text { Soil } \\
\text { specialization }\end{array}$ & $N$ \\
\hline \multirow[t]{2}{*}{ APOR } & Aporusa hosei Merr. & Phyllanthaceae & subcanopy tree & simple, alternate & sandy loam & 5 \\
\hline & Aporusa sarawakensis A. Schott & Phyllanthaceae & subcanopy tree & simple, alternate & clay & 5 \\
\hline \multirow[t]{2}{*}{ CALO } & Calophyllum ferrugineum Merr. & Clusiaceae & tree & simple, opposite & sandy loam & 6 \\
\hline & Calophyllum gracilipes Merr. & Clusiaceae & tree & simple, opposite & clay & 6 \\
\hline \multirow[t]{2}{*}{ DACR } & Dacryodes rostrata (B1.) Lam. f. cuspidata (B1.) Lam. & Burseraceae & tree & compound, alternate & clay & 3 \\
\hline & Dacryodes expansa (Ridl.) H.J. Lam & Burseraceae & tree & compound, alternate & sandy loam & 5 \\
\hline \multirow[t]{2}{*}{ DIOS } & Diospyros decipiens C.B. Clarke & Ebenaceae & tree & simple, alternate & clay & 5 \\
\hline & Diospyros ferruginescens Bakh. & Ebenaceae & tree & simple, alternate & sandy loam & 5 \\
\hline DIOSPE & Diospyros pendula Hasselt ex Hassk. & Ebenaceae & tree & simple, alternate & generalist & $4 \mathrm{C}, 5 \mathrm{SL}$ \\
\hline DIPTCT & Dipterocarpus confertus Sloot. & Dipterocarpaceae & canopy tree & simple, alternate & generalist & $5 \mathrm{C}, 6 \mathrm{SL}$ \\
\hline \multirow[t]{2}{*}{ DIPT } & Dipterocarpus globosus Vesque & Dipterocarpaceae & canopy tree & simple, alternate & sandy loam & 5 \\
\hline & Dipterocarpus kunstleri King & Dipterocarpaceae & tree & simple, alternate & clay & 8 \\
\hline \multirow[t]{2}{*}{ DRYO } & Dryobalanops aromatica C.F. Gaertn. & Dipterocarpaceae & canopy tree & simple, alternate & sandy loam & 5 \\
\hline & Dryobalanops lanceolata Burck & Dipterocarpaceae & canopy tree & simple, alternate & clay & 7 \\
\hline \multirow[t]{2}{*}{ MACA } & Macaranga lamellata Whitmore & Euphorbiaceae & subcanopy tree & simple, whorled & sandy loam & 6 \\
\hline & Macaranga umbrosa S.J. Davies & Euphorbiaceae & subcanopy tree & simple, whorled & clay & 4 \\
\hline \multirow{2}{*}{ PALA } & Palaquium cryptocariifolium P. Royen & Sapotaceae & tree & simple, whorled & sandy loam & 5 \\
\hline & Palaquium dasyphyllum Pierre ex Dubard & Sapotaceae & tree & simple, alternate & clay & 5 \\
\hline \multirow[t]{2}{*}{ POLY } & Polyalthia clavigera King & Annonaceae & tree & simple, alternate & sandy loam & 6 \\
\hline & Polyalthia sarawakensis Diels & Annonaceae & subcanopy tree & simple, alternate & clay & 7 \\
\hline POLYRU & Polyalthia rumphii (B1.) Merrill & Annonaceae & subcanopy tree & simple, alternate & generalist & $4 \mathrm{C}, 4 \mathrm{SL}$ \\
\hline \multirow[t]{2}{*}{ RINO } & Rinorea bengalensis (Wall.) Kuntze & Violaceae & subcanopy tree & simple, alternate & clay & 4 \\
\hline & Rinorea lanceolata Kuntze & Violaceae & subcanopy tree & simple, alternate & sandy loam & 5 \\
\hline \multirow[t]{2}{*}{ SHOR } & Shorea inappendiculata Burck & Dipterocarpaceae & canopy tree & simple, alternate & clay & 5 \\
\hline & Shorea laxa Slooten & Dipterocarpaceae & canopy tree & simple, alternate & sandy loam & 4 \\
\hline SHORPT & Shorea patoiensis Ashton & Dipterocarpaceae & canopy tree & simple, alternate & generalist & $5 \mathrm{C}, 5 \mathrm{SL}$ \\
\hline \multirow[t]{2}{*}{ EUGE } & Syzygium cf. grande (Wight) Walp. & Myrtaceae & tree & simple, opposite & sandy loam & 6 \\
\hline & Syzygium kingii (Merr.) Merr. \& L.M. Perry & Myrtaceae & tree & simple, opposite & clay & 5 \\
\hline
\end{tabular}

specialization within each genus (or species, for generalists). For all models, PPFD was included as a covariate. We chose not to model genus (or species, for generalists) as a random effect because visual inspection of mean trait values showed a nearly uniform distribution, indicating that the assumption that they came from a common distribution was not appropriate. Consistent with this, model comparison based on the Akaike information criterion (Bolker, 2007) showed greater support for the fixed-effects, relative to the mixed-effects, models (online Appendix S3), indicating in each case that variation in the dependent variable was better explained using independent intercept parameters for each group. Analyses with and without PPFD as a covariate (the latter included a larger number of trees) were consistent with each other, and only analyses with PPFD are presented. We also tested whether there was a consistent soil-type effect on stomatal traits across all genera (for specialists) and species (for generalists). Means of stomatal traits were calculated for each taxonomic group, and linear models with soil type and genus (or species, for generalists) as main effects were fitted.

Comparisons between congeneric species pairs allow a test of whether there are consistent trait shifts between specialists of each soil type, but do not account for the deeper evolutionary history that our study species share. To test for correlated evolution between stomatal gas exchange and water-use efficiency traits, we used analyses of phylogenetically independent contrast (PICs). We assembled a hypothesis of the phylogenetic relationships among the 28 species in our data based on the most recent, maximally resolved Angiosperm Phylogeny Group hypothesis (Stevens, 2001 onward) as represented in the software Phylomatic (available at http://www.phylodiversity.net/ phylomatic/, part of the phylodiversity network, sponsored by Arnold Arboretum of Harvard University), using a speciational model of evolution for branch lengths (Grafen, 1989). The phylogeny was not fully bifurcating. We therefore generated 5000 topologies comprising random resolutions of all nodes containing polytomies, then calculated independent contrasts, and performed a Pearson correlation for each. If the 95th percentile of the distribution of probabilities from the Pearson correlation tests was $\leq 0.05$, then that correlation was considered statistically significant, and the correlation coefficient $(r)$ was taken to be the 95th (for $r<0$ ) or 5 th (for $r>0$ ) percentile of the distribution of coefficients. We used the R package ape (R Development Core Team, 2006) for all phylogenetic comparative analyses.
We examined whether gas exchange and water-use efficiency parameters differed between soil types, accounting for variation in the light environments of individual trees (PPFD). Replication of gas exchange data were insufficient to model the effect of soil type within genera, so data for soil specialists were pooled across all species and individuals. The $2-4$ data points per species are, however, likely to be more similar to each other than to heterospecifics, potentially generating correlated errors. Therefore, models using individual-level data, but with a random effect on the individual tree, were used to account for the correlated error structure (Bolker, 2007). Relationships between species' means and PICs in stomatal, gas-exchange, and water-use traits were modeled using Pearson correlation (Zar, 1996). Log-transformation was used when required to improve normality of model residuals. The statistical package R $(\mathrm{R}$ Development Core Team, 2006) was used for all analyses.

\section{RESULTS}

Soil-related environmental variation-Soil volumetric water content was significantly higher on average throughout the year on the clay soil, relative to the sandy loam soil (no significant interaction between soil type and measurement date: $\mathrm{df}=406, t=0.57, P=0.569$; main effect of soil type: $\mathrm{df}=32$, $t=-6.70, P<0.001$; Fig. 1). Vapor pressure deficit at a given air temperature tended to be higher on sandy loam than on clay, although air temperatures also tended to be higher on clay than on sandy loam (Appendix S4, see online Supplemental Data). Understory light availability was significantly greater on the sandy loam, relative to the clay soil (Welch's $t$ test: $\mathrm{df}=91.2$, $t=-4.49, P<0.001)$, based on hemispherical photographs of the study trees. The mean and standard deviation (in parentheses) of average daily PPFD was 6.22 (1.24) and 5.15 (1.11) $\mathrm{mol} \cdot \mathrm{m}^{-2} \cdot \mathrm{day}^{-1}$ on the sandy loam and clay soils, respectively, corresponding to a $1.6 \%$ difference in canopy openness. 


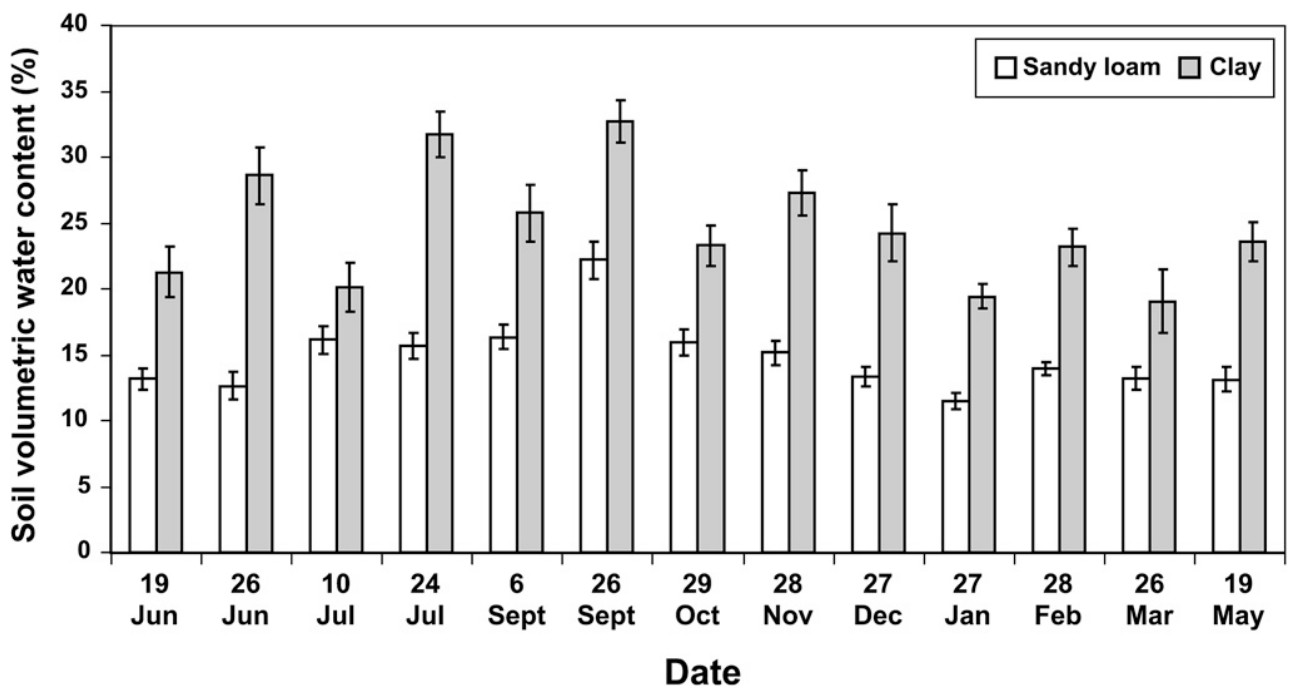

Fig. 1. Variation in soil volumetric water content between sandy loam and clay soils underlying mixed-dipterocarp forest in Borneo.

Stomatal traits-The 28 study species differed substantially in stomatal form (online Appendix S1) and varied 15-fold in mean stomatal density, 3-fold in guard cell length, and 6-fold in stomatal pore length (online Appendix S5). Mean guard cell length and stomatal pore length were highly correlated among species $(r=0.90, P<0.001)$. There was a significant negative correlation between species' mean stomatal density and guard cell length (species' values: $r=-0.72, P<0.001$; PICs: $r=$ $-0.72 ; P=0.003$; Fig. 2). Based on species' values, this relationship was fit by a power-law with a scaling exponent of $-1.78(\mathrm{SE}=0.34 ; \log ($ density $)=-1.78 \times \log ($ length $)+10.47 ;$ $F_{1,26}=27.91, P<0.001 R^{2}=0.50$ ).

Most species had few or no stomates on the adaxial surface of the lamina, with the exception of three clay specialists, Aporusa sarawakensis, Rinorea bengalensis, and Syzygium kingii. Adaxial densities of stomates were appreciably lower than the abaxial densities for A. sarawakensis and S. kingii. They were more comparable, but still significantly lower, for $R$. bengalensis (Student's $t$ test: $t=-5.90, \mathrm{df}=3.3, P=0.008$ ). Sizes of stomates for $R$. bengalensis were similar on the abaxial and adaxial surfaces (Student's $t$ test: $t=-1.24, \mathrm{df}=5.54, P=$ 0.263). Macaranga lamellata, a sandy loam specialist, was observed to have papillate structures on the leaf, with stomates embedded within them (online Appendix S1).

Soil-related inter- and intraspecific variation in stomatal traits-Differences between soil specialists within each genus explained more of the total variation in stomatal traits than did variation in light availability for all three stomatal traits (online Appendix S6). Stomatal traits varied greatly between soil specialists within each genus (Fig. 3), but not always in the predicted direction. We predicted that clay specialists would have significantly greater stomatal densities than sandy loam specialists, and this was true of the comparisons for three of 12 genera (Aporusa, Diospyros, and Syzygium; Fig. 3A). Two genera, Dipterocarpus and Polyalthia, had significantly greater stomatal densities on the leaves of sandy loam specialists, a pattern opposite to that predicted. For the remaining seven genera, there was no significant variation between specialists.

Clay specialists were expected to have leaves with significantly larger stomates (guard cell length) than sandy loam spe- cialists, and this was true of the comparisons for four of 12 genera (Dacryodes, Dipterocarpus, Palaquium, and Polyalthia; Fig. 3B). Three genera (Aporusa, Diospyros, and Syzygium) exhibited significantly larger stomates on the leaves of sandy loam specialists, a pattern opposite to that predicted. For the other five genera, there was no significant variation between specialists. Largely due to the negative correlation between stomatal density and size (Fig. 2), the genera that were consistent or inconsistent with our predictions shifted in the analyses of stomatal density and size.

We predicted that clay specialists would have significantly greater stomatal conducting capacity, as measured by the

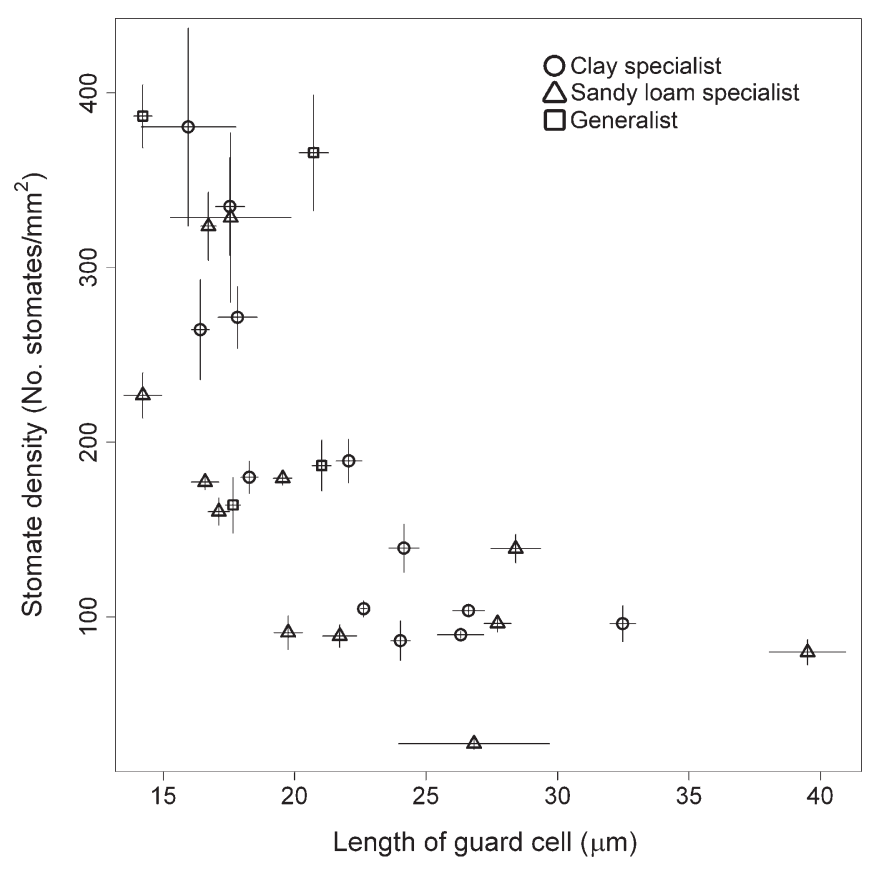

Fig. 2. The relationship between mean stomatal density and guard cell length among 28 Bornean tree species. Triangles and circles represent species specializing on sandy loam and clay soils, respectively; squares represent generalists. Error bars are \pm 1 standard error. 

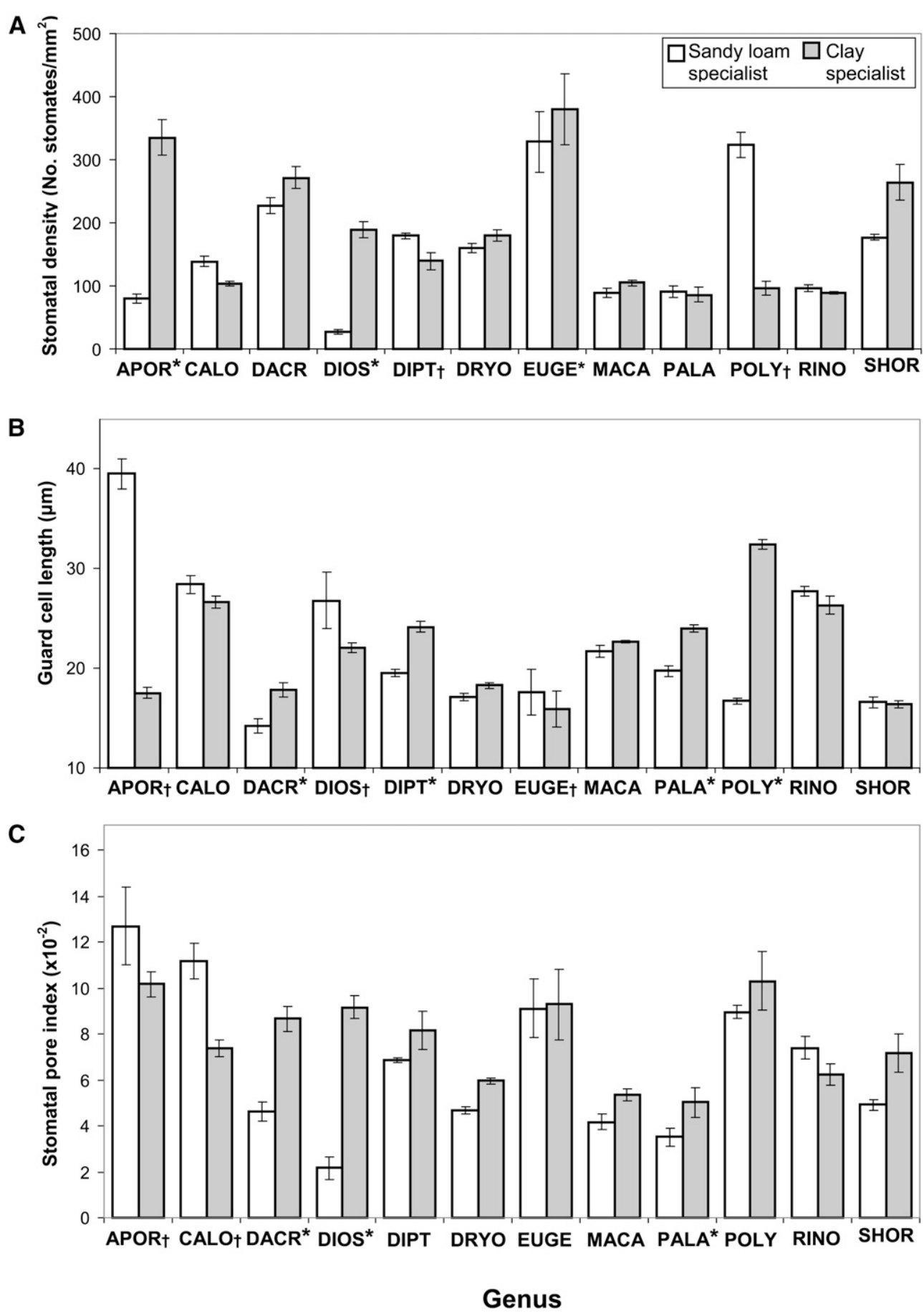

Fig. 3. Interspecific variation in stomatal density, guard cell length, and stomatal pore index between tree species specializing on sandy loam or clay soils in Bornean rain forest. Abbreviations for genera are given in Table 1 . Means \pm 1 standard error are shown. Asterisks and daggers on the $x$-axis indicate genera in which there were significant differences $(P<0.05)$ between soil specialists in the predicted, or opposite to the predicted, direction, respectively.

stomatal pore index (SPI), than would the sandy loam specialists, and for three of 12 genera, this prediction was borne out (Dacryodes, Diospyros, and Palaquium; Fig. 3C). For two genera (Aporusa and Calophyllum), the SPI of sandy loam specialists significantly exceeded that of clay specialists, contrary to our prediction. For the remaining six genera, there were no significant differences between soil specialists in SPI.
There was little soil-related phenotypic plasticity in stomatal traits among soil generalists (Fig. 4). None of the four generalist species exhibited statistically significant variation between populations growing on sandy loam vs. clay soils in any stomatal trait (online Appendix S7). Based on mean trait values for soil specialists and for populations of generalists on each soil type across all taxonomic groups, there were no significant differences between soils for any stomatal trait, which is likely due 

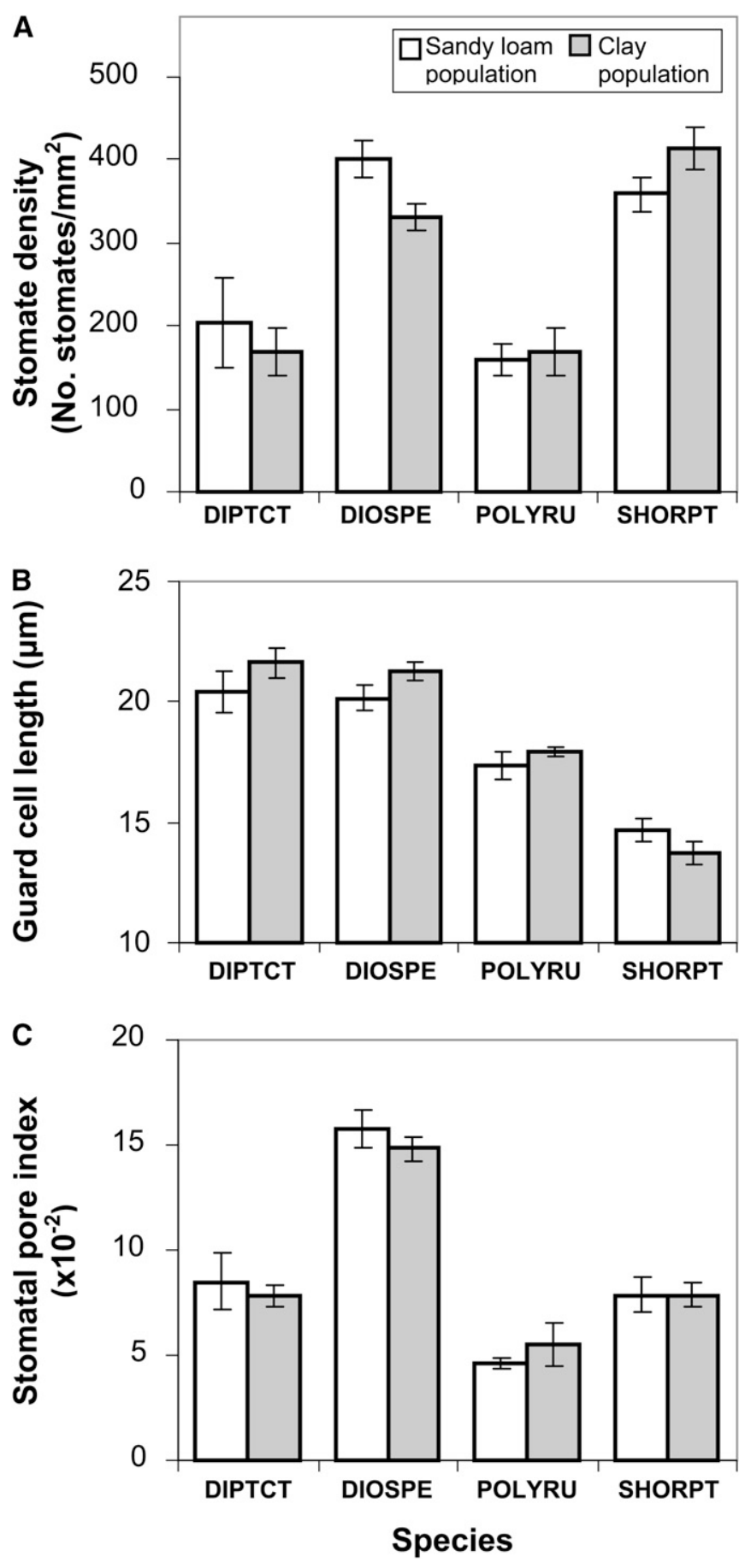

Fig. 4. Intraspecific variation in stomatal density, guard cell length, and stomatal pore index between populations of four generalist tree species growing on sandy loam or clay soils in Bornean rain forest. Abbreviations for genera are given in Table 1. Means \pm 1 standard error are shown. There were no significant differences between populations on each soil $(p>$ $0.05)$.

to the fact the direction of the significant effects of soil specialization differed among genera.

Covariation of gas exchange and water-use efficiency traits with light availability_Across all individuals, there was only marginally statistically significant covariation of daily average PPFD with $A_{\max }(P=0.049)$ and $g_{\max }(P=0.054)$. There was no significant covariation of PPFD with instantaneous WUE $(P=$ 0.434). Based on species mean values, there were no differences in $g_{\max }$ or instantaneous or integrated WUE between soil specialists $\left(F_{1,11}=1.29, P=0.280 ; F_{1,11}=0.05, P=0.834 ; F_{1,11}=\right.$ $3.87, P=0.0 .075$; respectively). However, $A_{\max }$ was higher for sandy loam than for clay specialists $(5.65$ vs. $4.67 \mu \mathrm{mol}$ $\mathrm{CO}_{2} \cdot \mathrm{m}^{-2} \cdot \mathrm{s}^{-1}$, respectively; $\left.F_{1,11}=7.02, P=0.023\right)$. Among soil specialists, the higher $A_{\max }$ on sandy loam remained significant after accounting for the light environment of individual trees (soil main effect, $P=0.018$; online Appendix S8), and individuals of sandy loam specialists displayed a slightly stronger relationship between $A_{\max }$ and light (sandy loam: slope $=0.04$, standard error of slope $=0.03, P=0.137, \mathrm{df}=25$; clay: slope $=$ 0.01 , standard error of slope $=0.04, P=0.716, \mathrm{df}=18$ ). This is likely explained by acclimation to the overall higher understory irradiance on sandy loam than clay. A similar but weaker trend was observed in mean $A_{\max }$ of generalist individuals (5.18 vs. $4.93 \mu \mathrm{mol} \mathrm{CO} \mathrm{CO}_{2} \cdot \mathrm{m}^{-2} \cdot \mathrm{s}^{-1}$ for sandy loam vs. clay), but the effect of soil type was not significant, although this test had lower replication than that for specialists $\left(F_{1,14}=0.15, P=0.705\right)$.

Relationships between stomatal and gas exchange or wateruse efficiency traits - There were relatively few significant interspecific relationships between stomatal traits and either gas exchange or water-use efficiency variables, based on species' values (Fig. 5) and PICs. Based on species' values and PICs, $A_{\max }$ was not significantly related to any stomatal trait. Similarly, contrary to expectation, $g_{\max }$ was not related to mean SPI (Fig. 5J), nor to either of the components of SPI, stomatal size or density (Fig. 5B and 5F).

Although there was no significant relationship between the time-integrated estimate of WUE ( $\Delta^{13} \mathrm{C}$ of leaves) and any stomatal trait based on species' values and PICs, there was a strong negative relationship between instantaneous WUE $\left(A_{\max } / g_{\max }\right)$ and stomatal size (Fig. 5C) and, more weakly, with stomatal density (Fig. 5G) based on species' values. For the relationship between instantaneous WUE and stomatal size, the shape of the scatterplot suggests a boundary relationship in that, for a given guard cell length, there appears to be a maximum attainable instantaneous WUE. Thus, variation in instantaneous WUE appears to be driven more by variation in stomatal size than density or total conducting capacity (as measured by SPI), and increases in instantaneous WUE appear to require reduction in the size of stomates. However, this relationship was not statistically significant after accounting for phylogeny using PICs.

\section{DISCUSSION}

Despite high rainfall, interspecific variation in nutrient- and water-use efficiency and drought-tolerance have been shown to be important determinants of the distributions of tropical tree species (Brunig, 1974; Baltzer et al., 2005, 2008; Engelbrecht et al., 2007), and periodic drought at Lambir and elsewhere in Southeast Asia can increase tree mortality rates (Becker and Wong, 1993; Burslem et al., 1996; Delissio and Primack, 2003; Potts, 2003; Newbery and Lingenfelder, 2004). In addition, studies based on theory and observation generally have found coordination among leaf hydraulic architecture, resistance to water vapor diffusion, and stomatal traits (Parlange and Waggoner, 1970; Sack et al., 2003; Franks, 2004). We therefore 

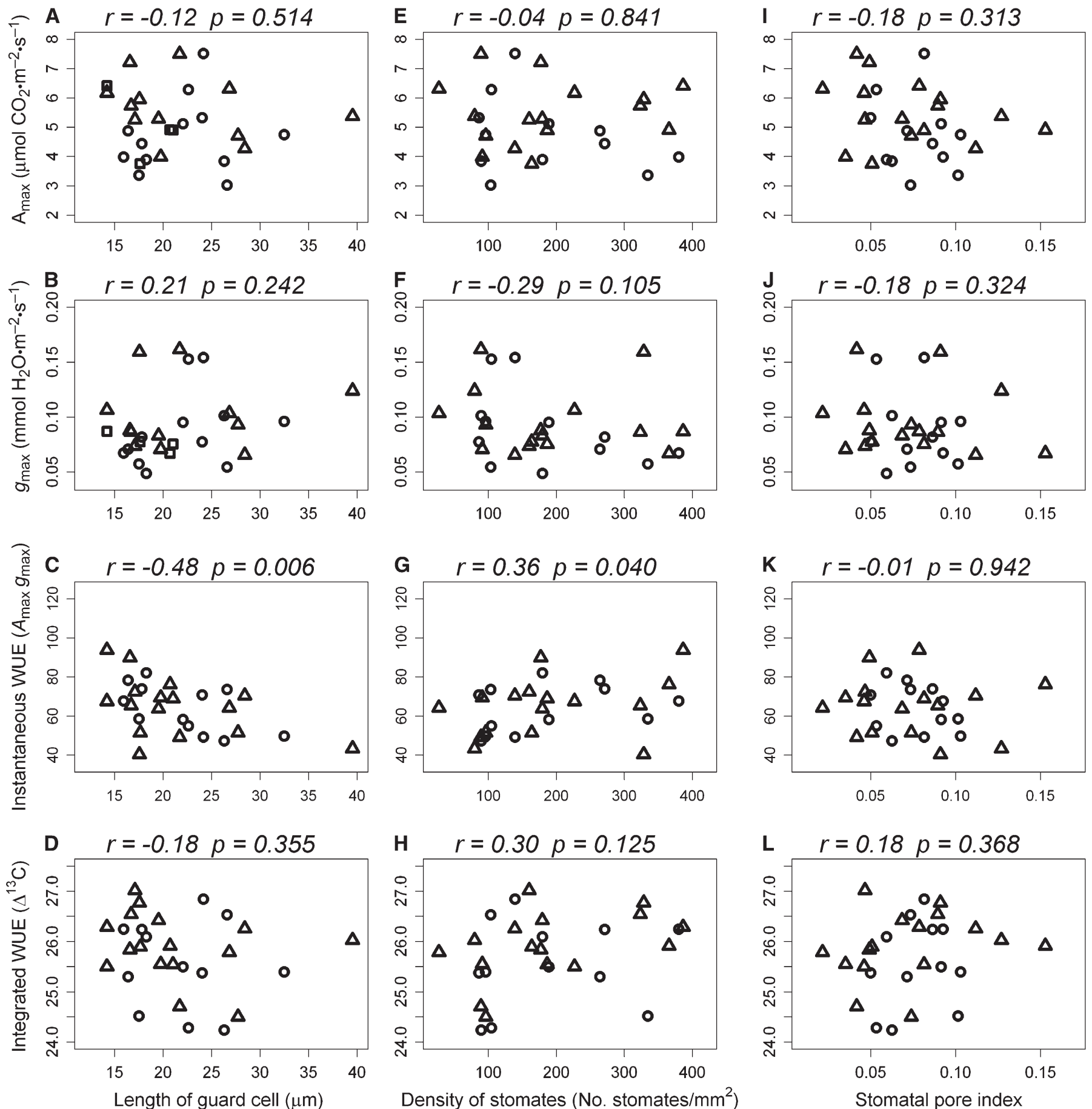

Fig. 5. The correlation of mean stomatal density, mean guard cell length, and mean stomatal pore index with gas exchange and water-use efficiency parameters for 28 Bornean tree species. Pearson correlation coefficients $(r)$ and probabilities $(p)$ are listed above each plot. Triangles and circles represent species specializing on sandy loam and clay soils, respectively; squares represent generalists.

expected stomatal traits of tree species specializing on different soil types to reflect variation in the availability of soil moisture and nutrients and for variation between stomatal, gas exchange, and WUE traits to be correlated. Our results, however, provide only weak support for these ideas: SPI, a measure of the maximum stomatal conducting capacity of a leaf, was larger for tree species specializing on the more fertile, moister clay soil in only three of 12 congeneric comparisons. Furthermore, the substantial diversity in stomatal anatomy observed among these Bornean tree species did not strongly correlate with function. Of the gas exchange and water-use efficiency parameters that we measured, the only significant relationship with a stomatal trait was between species' mean instantaneous water-use efficiency and stomatal size. 
Implications for understanding species' distributions-Our findings have a number of important implications for understanding the distributions of tree species along resource gradients. First, gradients vary simultaneously in multiple resources, and at least for some taxa at Lambir, soil moisture may not be the key factor directly determining species' distributions along this edaphic gradient. Although this inference is in contrast to some findings in other tropical forests (e.g., Baltzer et al., 2005, 2008; Engelbrecht et al., 2007), there is no reason to expect that water should be the most important limiting resource in all tropical forests. Furthermore, tolerance of catastrophic drought, rather than responses to the routine differences in water availability that are measured by water-use efficiency parameters, may be more important in determining species' distributions in this ever-wet forest (Becker and Wong, 1993; Burslem et al., 1996; Delissio and Primack, 2003; Potts, 2003; Newbery and Lingenfelder, 2004; Blackman et al., 2009). Thus, although many studies have demonstrated that tree species are associated with and exhibit varying performance in particular soil-defined habitat types (e.g., Clark et al., 1998; Davies et al., 2005; Russo et al., 2005; Paoli et al., 2006; Comita and Engelbrecht, 2009), fewer studies have evaluated which of the several possible resources that vary along gradients, and the nature of their restriction, are the most important in explaining those distributions.

Second, the fact that the availability of different types of resources can covary inversely along soil-defined resource gradients (Coomes and Grubb, 2000; present study) has consequences for natural selection on and the resulting diversity of functional traits. At Lambir, the clay soil is more productive in that it supports significantly faster diameter growth than does the lessfertile, better-drained sandy loam soil (Russo et al., 2005). In such productive habitats, species with higher $A_{\max }$ would presumably have a competitive advantage (Poorter and Garnier, 1999), which could indirectly select for coordinated increases in $g_{\max }$ and SPI (Geber and Dawson, 1997; Arntz and Delph, 2001). In contrast to the availability of soil resources at Lambir, understory light is more limited on clay than on sandy loam due to denser canopy cover, and this would presumably result in opposing selection on these traits. $A_{\max }$ of saplings appeared to respond more to variation in the availability of understory light than directly to availability of soil resources, since $A_{\max }$ was higher and displayed a slightly stronger relationship with light on the less fertile, well-drained sandy loam soil, compared to clay. Functional traits are thus likely to experience conflicting environmental selection pressures, even on the same habitat type, which has the potential to maintain genetic variation and result in the large within-species variance in trait values that we observed (Levins, 1968).

Third, the fitness consequences of variation in a particular trait, such as SPI, depend on its integration with other traits in the whole plant (Reich et al., 2003; Marks and Lechowicz, 2006). In other words, traits can be integrated functionally in quantitatively different ways that result in similar whole-plant performance: such higher-order functional integration has been shown in a simulation model of tree seedling growth and survival to contribute to functional trait diversity in forests via selection for alternative functional designs (Marks and Lechowicz, 2006). Stomatal, gas exchange, and water-use efficiency traits should therefore be considered as only part of the overall functional program influencing the performance of these Bornean tree species, and they are expected to be integrated with other traits, such as those related to hydraulic conductance and vascular anatomy (Meinzer et al., 1997; Brodribb et al., 2003; Sack, et al., 2003). For example, all else being equal, similar rates of $\mathrm{CO}_{2}$ diffusion to the sites of carboxylation could be achieved by different combinations of SPI, stomatal pore depth, and thickness of the mesophyll (Nobel, 2009). Our results suggest that in the clades represented at Lambir by our 12 study genera, alternative functional designs for gas exchange may contribute both to the diversity in stomatal traits and to the lack of correlation between stomatal traits and photosynthetic and WUE responses observed along this edaphic gradient.

Stomatal traits in relation to WUE and gas exchange-The weak relationships between stomatal, gas exchange, and WUE traits may also be explained because stomatal anatomy (SPI) is not the only determinant of conductance. In humid, shaded understories, where our study was conducted, carbon fixation is strongly light-limited. Our results suggest that carbon assimilation may have been more constrained by light limitation than by any direct, soil-related effects that stomatal traits may have on water loss from or $\mathrm{CO}_{2}$ diffusion to the sites of carboxylation in the leaf. Even in the saturating light of gas exchange measurements, it is possible that stomates may not have been fully open, due to acclimation to their extremely shaded environments (Chazdon and Pearcy, 1986). If so, our $g_{\max }$ estimates would not reflect the maximal conducting capacity of stomates of these dimensions and densities. Instead, our data suggest that the saplings of these Bornean tree species have higher SPI than is necessary to achieve the $g_{\max }$ and $A_{\max }$ that are realizable in the shaded understory. Cornelissen et al. (2003) also found the leaves of shaded, laboratory-grown seedlings to be over-built in terms of SPI, relative to leaves on adults in higher irradiance. Furthermore, conductance inversely scales with stomatal pore depth $\left[g_{\max } \propto \mathrm{SPI} /(\right.$ stomatal depth + stomatal pore radius); (Ting and Loomis, 1963; Parlange and Waggoner, 1970; Ajiri et al., 1973; Sack et al., 2003)]. We lack information on stomatal pore depths of these Bornean tree species, but given the variability in stomatal form (Appendix S1), they may also vary in pore depth, which could account for the lack of correlation between $g_{\max }$ and SPI. Interference between neighboring stomates and wax occlusions over the pore would also increase resistance to diffusion through stomates (Ting and Loomis, 1965; Parlange and Waggoner, 1970; Ajiri et al., 1973). The dispersion of stomates on the epidermis varied from appearing clustered (e.g., Dryobalanops spp.) to more regular (e.g., Aporusa spp.), and stomatal pores of some species appeared more occluded than those of others (Appendix S1). Variation among species in these features would also act to decouple the interspecific relationship between $g_{\max }$ and SPI.

Stomatal pore index is a function of stomatal density and guard cell length, and we found these latter traits to be negatively related, in parallel to other studies (Salisbury, 1928; Grubb et al., 1975; Bongers and Popma, 1990; Sack et al., 2003, 2005). The scaling exponent fit to our data were within two standard errors of that found for six temperate tree species (Sack et al., 2003). Increases in SPI can therefore be achieved by increases in stomatal density or size, but apparently not both simultaneously. Such a scaling constraint on SPI might be expected if either the size or density is developmentally fixed based on the rate of leaf expansion (Salisbury, 1928) or if the maximal capacity for stomatal conductance is coordinated with the maximal capacity for carbon fixation so as not to exceed it (Cowan, 1977; Farquhar et al., 1980). If the stomatal size-density relationship were driven purely by constraints associated with leaf expansion, then we would not necessarily expect to 
see an evolutionary correlation between these traits. The fact that the analyses based on PICs showed a significant relationship provides more support for the hypothesis that evolutionary coordination between the maximal capacities for stomatal conductance and C-fixation (Geber and Dawson, 1997; Arntz and Delph, 2001) may underlie the scaling relationship.

Published findings relating variation in stomatal traits to water stress and mineral nutrient availability are inconsistent. Studies in Southeast Asian heath and Brazilian caatinga forests, which can experience extreme, periodic drought stress, also failed to find a relation between leaf anatomy, including stomatal characters, and traits related to drought tolerance (Ferri, 1960; Peace and McDonald, 1981; Medina et al., 1990; Juhrbandt et al., 2004). Moreover, another study of Bornean tree species also observed no significant covariation between stomatal and gas exchange traits (Cao and Booth, 2001). Nevertheless, our results contrast with studies finding SPI and stomatal density to be associated with maximal stomatal or whole-leaf epidermal conductance (Koerner et al., 1979; Sack et al., 2003, 2004; Juhrbandt et al., 2004).

Phenotypic plasticity in stomatal traits-We found no evidence of phenotypic plasticity in stomatal density or guard cell length among conspecific individuals that could be explained by edaphic variation. Applying this finding to the soil specialists suggests that significant differences between specialists in stomatal traits, when they were found, were likely to be better explained by genotypic differences between species than by phenotypic plasticity in response to soil-related environmental variation. Our result is consistent with an experiment in which there was no change in the stomatal density or guard cell length of individuals fertilized with nitrogen, relative to unfertilized controls, for six temperate deciduous tree species (Aasamaa et al., 2001). That study did, however, find that experimentally water-stressed individuals exhibited reduced guard cell length, but no change in stomatal density, relative to unstressed controls.

Stomatal traits are generally found to vary between sun and shade leaves of the same species (Abrams and Kubiske, 1990; Poole et al., 1996; Herrick et al., 2004; Sack et al., 2006). The fact that we did not observe within-species differences in stomatal traits of generalists growing on sandy loam vs. clay suggests that the magnitude of variation between soil types in understory light was not strong enough to induce them. The lack of plasticity that we observed may partly result from the fact that all generalists examined for plasticity are very shade tolerant. Extremely shade-tolerant species are considered to be less flexible in growth rate, structure, and physiology, compared to more light-demanding species (Bazzaz, 1979; Abrams and Kubiske, 1990; Chazdon, 1992).

Conclusions-Identifying the functional basis of performance differences of juvenile trees as they compete for a spot in the canopy is critical to understanding forest community dynamics. In tropical forests, it is still a matter of debate whether mineral nutrient limitation, water deficit, or herbivory most strongly controls functional trait variation and the distribution of tree species along edaphic gradients (Janzen, 1974; Peace and Mcdonald, 1981; Medina et al., 1990; Palmiotto et al., 2004; Baltzer et al., 2005, 2008; Fine et al., 2006). Denser canopies, however, form over more fertile, compared with less fertile, soils (Ashton, 1964; Coomes and Grubb, 2000; present study). As such, light availability is also likely to play a significant role in determining both the performance differences of trees in the understory and the functional trait variation that underlies those differences, even on edaphically defined resource gradients. Thus, multiple environmental factors and their interactions may make it difficult for low-dimensional functional trait trade-offs to be the principal determinants of performance (Ricklefs, 1977; Grubb, 1992; Clark et al., 2007). Indeed, we found strong covariation between stomatal density and size, but not between anatomical and functional traits of stomates among shaded juveniles of Bornean tree species. Instead, higher-order functional integration of traits (sensu Marks and Lechowicz, 2006) is likely to be more closely linked to the performance differences between tree species at the sapling stage that ultimately determine forest community structure.

\section{LITERATURE CITED}

AasamaA, K., A. Sober, And M. RAhi. 2001. Leaf anatomical characteristics associated with shoot hydraulic conductance, stomatal conductance and stomatal sensitivity to changes of leaf water status in temperate deciduous trees. Functional Plant Biology 28: 765-774.

Abramoff, M. D., P. J. Magelhaes, and S. J. Ram. 2004. Image processing with ImageJ. Biophotonics International 11: 36-42.

Abrams, M. D., AND M. E. KuBISKE. 1990. Leaf structural characteristics of 31 hardwood and conifer tree species in central Wisconsin: Influence of light regime and shade-tolerance rank. Forest Ecology and Management 31: 245-253.

ACKerly, D. D. 2003. Community assembly, niche conservatism, and adaptive evolution in changing environments. International Journal of Plant Sciences 164: S165-S184.

AJiri, S. I., J. T. Clayton, And C. S. Chen. 1973. Analysis of stomatal and convective resistances to transpirational flow. International Journal of Biometeorology 17: 337-343.

Arntz, A. M., And L. F. Delph. 2001. Pattern and process: Evidence for the evolution of photosynthetic traits in natural populations Oecologia 127: 455-467.

Ashton, P. S. 1964. Ecological studies in the mixed dipterocarp forests of Brunei state. Oxford Forestry Memoir 25: 1-75.

Ashton, P. S., AND P. HAll. 1992. Comparisons of structure among mixed dipterocarp forests of north-western Borneo. Journal of Ecology 80: 459-481.

Baillie, I. C., P. S. Ashton, S. P. Chin, S. J. Davies, P. A. Palmiotto, S. E. Russo, AND S. TAN. 2006. Spatial associations of humus, nutrients, and soils in mixed dipterocarp forest at Lambir, Sarawak, Malaysian Borneo. Journal of Tropical Ecology 22: 543-553.

Baillie, I. C., P. S. Ashton, M. N. Court, J. A. R. Anderson, E. A. FitzPATRICK, AND J. Tinsley. 1987. Site characteristics and the distribution of tree species in mixed dipterocarp forest on Tertiary sediments in Central Sarawak, Malaysia. Journal of Tropical Ecology 3: 201-220.

Baltzer, J. L., S. J. Davies, S. Bunyavejchewin, and N. S. M. Noor. 2008. The role of desiccation tolerance in determining tree species distributions along the Malay-Thai Peninsula. Functional Ecology 22: 221-231.

Baltzer, J. L., S. C. Thomas, R. Nilus, and D. F. R. P. Burslem. 2005 Edaphic specialization in tropical trees: Physiological correlates and responses to reciprocal transplantation. Ecology 86: 3063-3077.

BAzzaz, F. A. 1979. The physiological ecology of plant succession. Annual Review of Ecology and Systematics 10: 351-371.

BeCKer, P., AND M. Wong. 1993. Drought-induced mortality in tropical heath forest. Journal of Tropical Forest Science 5: 416-419.

Blackman, C. J., T. J. BrodribB, And G. J. Jordan. 2009. Leaf hydraulics and drought stress: Response, recovery and survivorship in four woody temperate plant species. Plant, Cell \& Environment 32: 1584-1595.

Bolker, B. M. 2007. Ecological models and data in R. Princeton University Press, Princeton, New Jersey, USA.

Bongers, F., AND J. Popma. 1990. Leaf characteristics of the tropical rain forest flora of Los Tuxtlas, Mexico. Botanical Gazette 151: 354-365. 
Brodribb, T. J., N. M. Holbrook, E. J. Edwards, ANd M. V. Gutierrez. 2003. Relations between stomatal closure, leaf turgor and xylem vulnerability in eight tropical dry forest trees. Plant, Cell \& Environment 26: $443-450$.

Brodribb, T. J., S. A. M. McAdam, G. J. Jordan, And T. S. Feild. 2009. Evolution of stomatal responsiveness to $\mathrm{CO}_{2}$ and optimization of water-use efficiency among land plants. New Phytologist 183: 839-847.

BRUNIG, E. F. 1974. Ecological studies in the kerangas forests of Sarawak and Brunei. Borneo Literature Bureau, Kuching, Malaysia.

Burslem, D., P. J. Grubb, AND I. M. Turner. 1996. Responses to simulated drought and elevated nutrient supply among shade-tolerant tree seedlings of lowland tropical forest in Singapore. Biotropica 28: 636-648.

Campbell, G. S. 1977. An introduction to environmental biophysics. Springer-Verlag, New York, New York, USA.

CAO, K.-F., AND E. W. Воотн. 2001. Leaf anatomical structure and photosynthetic induction for seedlings of five dipterocarp species under contrasting light conditions in a Bornean heath forest. Journal of Tropical Ecology 17: 163-175.

Chapin, F. S. III. 1980. Mineral nutrition of wild plants. Annual Reviews of Ecology and Evolution 11: 233-260.

Chapin, F. S. III, K. Autumn, and F. Pugnaire. 1993. Evolution of suites of traits in response to environmental stress. American Naturalist 142: S78-S92.

Chazdon, R. L. 1992. Photosynthetic plasticity of two rain forest shrubs across natural gap transects. Oecologia 92: 586-595.

Chazdon, R. L., and R. W. Pearcy. 1986. Photosynthetic responses to light variation in rain forest species. I. Induction under constant and fluctuating light conditions. Oecologia 69: 517-523.

Clark, D. B., D. A. Clark, and J. M. Read. 1998. Edaphic variation and the mesoscale distribution of tree species in a neotropical rain forest. Journal of Ecology 86: 101-112.

Clark, J. S., M. Dietze, S. Chakraborty, P. K. Agarwal, I. Ibanez, S. LaDeau, and M. Wolosin. 2007. Resolving the biodiversity paradox. Ecology Letters 10: 647-659.

Comita, L. S., And B. M. J. Engelbrecht. 2009. Seasonal and spatial variation in water availability drive habitat associations in a tropical forest. Ecology 90: 2755-2765.

CondiT, R. 1998. Tropical forest census plots: Methods and results from Barro Colorado Island, Panama and a comparison with other plots. Springer, Berlin, Germany.

Coomes, D. A., AND P. J. GRUBb. 2000. Impacts of root competition in forests and woodlands: A theoretical framework and review of experiments. Ecological Monographs 70: 171-207.

Cornelissen, J. H. C., B. Cerabolini, P. Castro-Diez, P. VillarSalvador, G. Montserrat-Marti, J. P. Puyravaud, M. Maestro, ET AL. 2003. Functional traits of woody plants: Correspondence of species rankings between field adults and laboratory-grown seedlings? Journal of Vegetation Science 14: 311-322.

Cowan, I. R. 1978. Stomatal behaviour and environment. Advances in Botanical Research 4: 117-228.

Cowan, I. R., AND G. D. Farquhar. 1977. Stomatal function in relation to leaf metabolism and environment. Symposia of the Society for Experimental Biology 31: 471-505.

Davies, S. J., S. Tan, J. V. LaFrankie, and M. D. Potts. 2005. Soilrelated floristic variation in the hyperdiverse dipterocarp forest in Lambir Hills, Sarawak. In D. W. Roubik, S. Sakai, and A. Hamid [eds.], Pollination ecology and rain forest diversity, Sarawak Studies, 22-34. Springer-Verlag, New York, New York, USA.

Delissio, L. J., and R. B. Primack. 2003. The impact of drought on the population dynamics of canopy-tree seedlings in an aseasonal Malaysian rain forest. Journal of Tropical Ecology 19: 489-500.

Engelbrecht, B. M. J., L. S. Comita, R. Condit, T. A. Kursar, M. T. Tyree, B. L. Turner, and S. P. Hubbell. 2007. Drought sensitivity shapes species distribution patterns in tropical forests. Nature 447 : $80-83$.

Farquhar, G. D., M. H. O'Leary, and J. A. Berry. 1982. On the relationship between carbon isotope discrimination and the intercellular carbon dioxide concentration of leaves. Australian Journal of Plant Physiology 9: 121-137.
FARQUhaR, G. D., AND R. A. RichaRds. 1984. Isotopic composition of plant carbon correlates with water-use efficiency of wheat genotypes. Australian Journal of Plant Physiology 11: 539-552.

Farquhar, G. D., E. D. Schulze, And M. Kuppers. 1980. Responses to humidity by stomata of Nicotiana glauca L. and Corylus avellana $\mathrm{L}$. are consistent with the optimization of carbon dioxide uptake with respect to water loss. Australian Journal of Plant Physiology 7: 315-327.

Ferri, M. G. 1960. Contribution to the knowledge of the ecology of the "Rio Negro Caatinga" (Amazon). Bulletin of the Research Council of Israel, D, Botany 89.

Fine, P. V. A., Z. J. Miller, I. Mesones, S. Irazuzta, H. M. Appel, M. H. H. Stevens, I. SaAksjarvi, et al. 2006. The growth-defense trade-off and habitat specialization by plants in Amazonian forests. Ecology 87: 150-162.

FranKs, P. J. 2004. Stomatal control and hydraulic conductance, with special reference to tall trees. Tree Physiology 24: 865-878.

Geber, M. A., AND T. E. Dawson. 1997. Genetic variation in stomatal and biochemical limitations to photosynthesis in the annual plant, Polygonum arenastrum. Oecologia 109: 535-546.

GivNish, T. 1988. Adaptation to sun and shade: A whole-plant perspective. Australian Journal of Plant Physiology 15: 63-92.

Grafen, A. 1989. The phylogenetic regression. Philosophical Transactions of the Royal Society of London. B, Biological Sciences 326: $119-157$.

Grime, J. P. 2001. Plant strategies, vegetation processes and ecosystem properties. John Wiley, New York, New York, USA.

GrubB, P. J. 1992. A positive distrust in simplicity-Lessons from plant defences and from competition among plants and among animals. Journal of Ecology 80: 585-610.

Grubb, P. J., E. A. Grubb, And I. Miyata. 1975. Leaf structure and function in evergreen trees and shrubs of Japanese warm temperate rain forest. I. Structure of lamina. Botanical Magazine-Tokyo 88: 197-211.

Hanba, Y. T., H. Kogami, and I. Terashima. 2003. The effect of internal $\mathrm{CO}_{2}$ conductance on leaf carbon isotope ratio. Isotopes in Environmental and Health Studies 39: 5-13.

Herrick, J. D., H. Maherali, and R. B. Thomas. 2004. Reduced stomatal conductance in sweetgum (Liquidambar styraciflua) sustained over long-term $\mathrm{CO}_{2}$ enrichment. New Phytologist 162: 387-396.

JANZEN, D. H. 1974. Tropical blackwater rivers, animals, and mast fruiting by the Dipterocarpaceae. Biotropica 6: 69-103.

Juhrbandt, J., C. Leuschner, AND D. HöLscher. 2004. The relationship between maximal stomatal conductance and leaf traits in eight Southeast Asian early successional tree species. Forest Ecology and Management 202: 245-256.

Koerner, C., J. A. Scheel, And H. Bauer. 1979. Maximum leaf diffusive conductance in vascular plants. Photosynthetica 13: 45-82.

KozlowsKi, T., AND S. Pallardy. 2002. Acclimation and adaptive responses of woody plants to environmental stresses. Botanical Review 68: 270-334.

Lai, C. T., J. R. Ehleringer, A. J. Schauer, P. P. Tans, D. Y. Hollinger, K. T. Paw U, J. W. Munger, and S. C. Wofsy. 2005. Canopyscale ${ }^{13} \mathrm{C}$ of photosynthetic and respiratory $\mathrm{CO}_{2}$ fluxes: Observations in forest biomes across the United States. Global Change Biology 11: 633-643.

Lee, H. S., S. J. Davies, J. V. LaFrankie, S. Tan, T. Yamakura, A. Iтoн, T. Онкubo, AND O. Ashton. 2002. Floristic and structural diversity of mixed dipterocarp forests in Lambir Hills National Park, Sarawak, Malaysia. Journal of Tropical Forest Science 14: 379-400.

Levins, R. 1968. Evolution in changing environments. Princeton University Press, Princeton, New Jersey, USA.

Maherali, H., M. E. Sherrard, M. H. Clifford, and R. G. Latta. 2008. Leaf hydraulic conductivity and photosynthesis are genetically correlated in an annual grass. New Phytologist 180: 240-247.

Marks, C. O., AND M. J. LeChOwICZ. 2006. Alternative designs and the evolution of functional diversity. American Naturalist 167: 55-66.

Medina, E., V. Garcia, and E. Cuevas. 1990. Sclerophylly and oligotrophic environments: Relationships between leaf structure, mineral 
nutrient content, and drought resistance in tropical rain forests of the Upper Rio Negro region. Biotropica 22: 51-64.

MeInZER, F. C. 2002. Co-ordination of vapour and liquid phase water transport properties in plants. Plant, Cell \& Environment 25: 265-274

Meinzer, F. C., J. L. Andrade, G. Goldstein, N. M. Holbrook, J. Cavelier, and P. Jackson. 1997. Control of transpiration from the upper canopy of a tropical forest: The role of stomatal, boundary layer and hydraulic architecture components. Plant, Cell \& Environment 20: $1242-1252$

MurRay, F. W. 1967. On the computation of saturation vapor pressure. Journal of Applied Meteorology 6: 203-204.

Newbery, D. M., AND M. Lingenfelder. 2004. Resistance of a lowland rain forest to increasing drought intensity in Sabah, Borneo. Journal of Tropical Ecology 20: 613-624.

Nobel, P. S. 2009. Physicochemical and environmental plant physiology. Academic Press, New York, New York, USA.

Palmiotto, P. A., S. J. Davies, K. A. Vogt, M. S. Ashton, D. J. Vogt, and P. S. Ashton. 2004. Soil-related habitat specialization in dipterocarp rain forest tree species in Borneo. Journal of Ecology 92: 609-623.

PaOli, G. D., L. M. Curran, AND D. R. ZAK. 2006. Soil nutrients and beta diversity in the Bornean Dipterocarpaceae: Evidence for niche partitioning by tropical rain forest trees. Journal of Ecology 94: 157-170.

Parlange, J.-Y., And P. E. Waggoner. 1970. Stomatal dimensions and resistance to diffusion. Plant Physiology 46: 337-342.

Peace, W. J. H., And F. D. Mcdonald. 1981. An inverstiagation of the leaf anatomy, foliar mineral levels, and water relations of trees of a sarawak forest. Biotropica 13: 100-109.

Poole, I., J. D. B. Weyers, T. Lawson, and J. A. Raven. 1996 Variations in stomatal density and index: Implications for palaeoclimatic reconstructions. Plant, Cell \& Environment 19: 705-712.

Poorter, H., AND E. Garnier. 1999. Ecological significance of inherent variation in relative growth rate and its components. In F. I. Pugnaire and F. Vallardes [eds.], Handbook of functional plant ecology, 82120. Marcel Dekker, New York, New York, USA.

PotTs, M. D. 2003. Drought in a Bornean everwet rain forest. Journal of Ecology 91: 467-474.

Potts, M. D., P. S. Ashton, L. S. Kaufman, and J. B. Plotkin. 2002. Habitat patterns in tropical rain forests: A comparison of 105 plots in northwest Borneo. Ecology 83: 2782-2797.

R Development Core Team. 2006. A language and environment for statistical computing. R Foundation for Statistical Computing, Vienna, Austria.

Reich, P. B., I. J. Wright, J. Cavender-Bares, J. M. Craine, J. Oleksyn, M. Westoby, and M. B. Walters. 2003. The evolution of plant functional variation: Traits, spectra, and strategies. International Journal of Plant Sciences 164: S143-S164.

RiCKLEFS, R. E. 1977. Environmental heterogeneity and plant species diversity: A hypothesis. American Naturalist 111: 376-381.
Russo, S. E., S. J. Davies, D. A. KIng, And S. Tan. 2005. Soil-related performance variation and distributions of tree species in a Bornean rain forest. Journal of Ecology 93: 879-889.

Sack, L., P. D. Cowan, N. Jaikumar, and N. M. Holbrook. 2003. The 'hydrology' of leaves: Co-ordination of structure and function in temperate woody species. Plant, Cell \& Environment 26 : $1343-1356$.

Sack, L., P. J. Melcher, W. H. Liu, E. Middleton, and T. Pardee. 2006. How strong is intracanopy leaf plasticity in temperate deciduous trees? American Journal of Botany 93: 829-839.

Sack, L., M. T. Tyree, AND N. M. Holbrook. 2005. Leaf hydraulic architecture correlates with regeneration irradiance in tropical rainforest trees. The New Phytologist 167: 403-413.

SAlisbury, E. J. 1928. On the causes and ecological significance of stomatal frequency, with special reference to the woodland flora. Philosophical Transactions of the Royal Society of London, B, Biological Sciences 216: 1-65.

Schauer, A. J., C. T. Lai, D. R. Bowling, and J. R. Ehleringer. 2003. An automated sampler for collection of atmospheric trace gas samples for stable isotope analyses. Agricultural and Forest Meteorology 118 : 113-124.

Seibt, U., A. Rajabi, H. Griffiths, and J. Berry. 2008. Carbon isotopes and water use efficiency: Sense and sensitivity. Oecologia 155: 441-454.

Stevens, P. F. 2001 onward. Angiosperm Phylogeny Website, version 9 [June 2008 and more or less continuously updated since], website http://www.mobot.org/MOBOT/research/APweb/.

Tan, S., T. Yamakura, M. Tani, P. Palmiotto, J. D. Mamit, C. S. Pin, S. Davies, P. Ashton, and I. Baillie. 2009. Review of soils on the 52-ha long term ecological research plot in mixed dipterocarp forest at Lambir, Sarawak, Malaysian Borneo. Tropics 18: 61-86.

Ting, I. P., AND W. E. Loomis. 1963. Diffusion through stomates. American Journal of Botany 50: 866-872.

TING, I. P., AND W. E. LoOMIs. 1965. Further studies concerning stomatal diffusion. Plant Physiology 40: 220-228.

Watson, H. 1985. Lambir Hills National Park: Resource inventory with management recommendations. National Parks and Wildlife Office, Forest Department, Kuching, Sarawak, Malaysia.

Weiner, E., AND P. A. KedDY. 1999. Ecological assembly rules: Perspectives, advances, retreats. Cambridge University Press, Cambridge, UK.

Westoby, M., D. S. Falster, A. T. Moles, P. A. Vesk, and I. J. Wright. 2002. Plant ecological strategies: Some leading dimensions of variation between species. Annual Review of Ecology and Systematics 33: $125-159$.

Zar, J. H. 1996. Biostatistical analysis. Prentice Hall, Upper Saddle River, New Jersey, USA. 